\title{
Evaluation of desertified delta plant communities using spectral indexes and landscape transformation models
}

\author{
Mamanbek Reimov ${ }^{1 *}$, Viktor Statov², Polat Reymov², Nizamatdin Mamutov², Salavat \\ Abdireymov $^{2}$, Yakhshimurad Khudaybergenov², Shynar Matchanova ${ }^{2}$ Aziz Orazbaev $^{2}$ \\ ${ }^{1}$ Tashkent Institute of Irrigation and Agricultural Mechanization Engineers, Tashkent, Kary Niyazi, \\ 39, Uzbekistan \\ 2 Karakalpak State University, Nukus, Ch. Abdirov 1, Uzbekistan
}

\begin{abstract}
The work concerns the application of spectral indexes (NDVI, SAVI and other types of spectral indexes) for monitoring and evaluation of the plant communities of desertified Amudarya river delta plant communities. The described approach includes the multi-level spatial model of the landscape transformation with desertification, soil erosion, soil salinity increasing, climatic changes to improve the adequacy of the remote sensing methods for complicated and non-stable post-deltaic ecosystems of the Aral Sea region. The key role of the geomorphological and pedological analysis for the spatial model implementation had been shown. Some geostatistical techniques had been used to link general data on vegetation cover calculated from remote sensing information with the type of the plant community, with consequent clarification of the vegetation map using both succession-based model approaches and field data.
\end{abstract}

Keywords. Environment, Plant Communities, Remote Sensing, Aral Disaster.

\section{Introduction}

Aral Sea crisis and geoecological monitoring. The Aral environmental disaster is one of the largest man-made natural crisis. Desiccation of the Sea and the lack of waters causes a lot of negative eco-logical trends in the Aral Sea region. There was a great impact on the delta of Amudarya River with the decay of unique ecosystem, with the lose of biodiversity as well as soil erosion and soil salinization. Transformation of the seashore and riparian landscapes of the low coarse of Amudarya river was a subject of intensive studies of outstanding geographers, botanists and soil scientists during a time of the Aral Sea devastation, and now we have some general view onto the process of the deltaic landscape

${ }^{*}$ Corresponding Author: nukusgiscenter@gmail.com 
transformation during desertification. But development of modern remote sensing methods, especially last results in processing of multi-spectral images and implementation of landscape trans-formation model allow to extend traditional method of change detection and give us new spatial representation of the delta desertification process $[1,2]$.

\section{Methods}

\subsection{Optical indexes as change detection tools.}

We used high-resolution space imaging from LANDSAT-7 and SETNTINEL satellites, SRTM-based DEM products and some retrospective information on Amudarya delta landscape transformation, including field data. All the space images after proper radiometric correction had been used to calculate of set of optical indexes to mirror current state of terrestrial ecosystem.

We calculate NDVI, SAVI, vegetation indexes, BI, GI, COSRI salinity indexes and some badland indexes (NBLI, EBBI) and wetness index (MNDVI). All these spatial referenced grids are combined into 3-dimensional array. Also we used MODIS-derived annual NDVI sequences to discriminate type of flora [3-7].

\subsection{Landscape change detection and plant communities. Landscape change model.}

V.A. Popov proposed an extinctive landscape transformation model for Amudarya delta using limited number of landscape classes, based on the water regime of the ecosystem presumably with some geomorphological corrections. His classification includes hydromorphic, mesomorphic, halomorphic, xeromorphic and anthropic landscapes. Transition coefficients from one landscape class (state of the ecosystem) had been derived from empirical data [8].

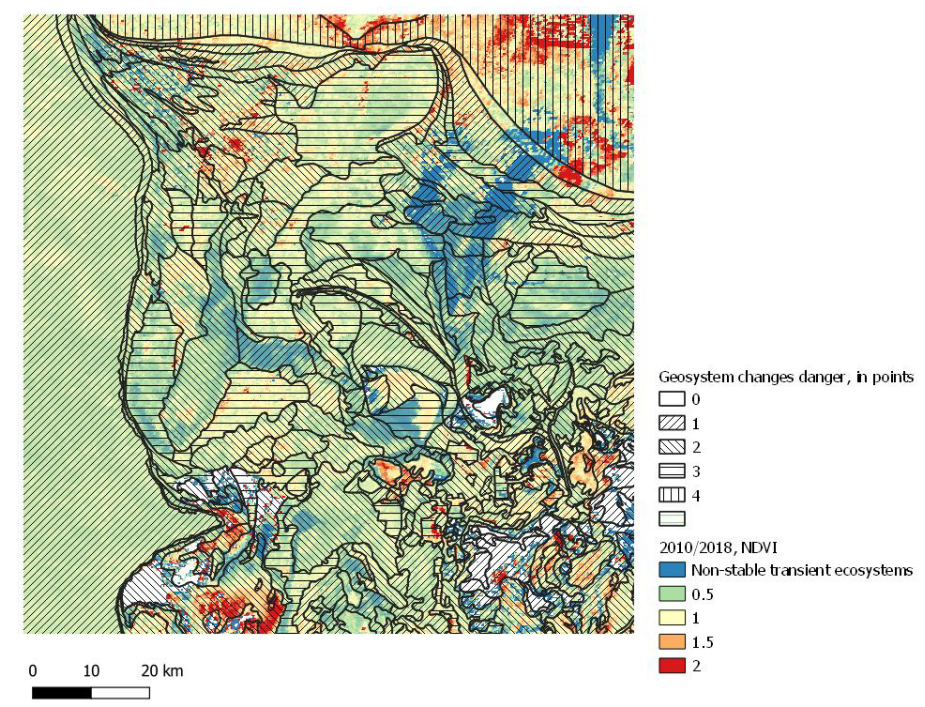

Fig1. Landscape changes map of Amudarya delta with ratio of inter-annual vegetation indexes. 
Also there is other plant community transformation model for Amu Darya delta based on the groundwater table and surface water accessibility $[9,10]$.

We suppose that primary landscape units changes as a whole system, under-going some external influence - climatic, edaphic, water stress, water table lowering and, thus we can simulate model landscape transformation as a pat-tern reconstruction [11]. Also, as any state in transformation sequence of the particular landscape unit is connected with specific plant communities and plant succession is a natural phenomenon confirmed with a lot of geobotanic indication exploration, we can extrapolate accumulated information about local flora development for the modern and foretasted stages of landscape transformation.

Notwithstanding reaction of the every landscape unit on the disturbances has some individual features, geoecological and botanical laws support some constant trends during desertification process.

Landscape transformation in deltaic ecosystem is a path-dependency phenomena, as current state of the landscape unit depends on local geomorphology, soils, site position in hydrology network and, in that way, we got additional crucial prerequisites to evaluate further transformation details, treating reference data collected during past decades by numerous researchers of Amudaria delta [12-18].

This empirical-based transition matrix can be used to determine possible landscape transformation detected through changes of spectral indexes, and, using known consistent pattern of the plant community's digression, we can make some prognoses on vegetation characteristics and geomorphological properties of the parcel, connected with soil properties (fig.2) [17].

\begin{tabular}{|c|c|c|}
\hline & Geosystems & $\begin{array}{l}\text { Changes in optical indexes and landscape picture of } \\
\text { the Earth Surface under investigation }\end{array}$ \\
\hline \multirow{5}{*}{$\downarrow$} & \multicolumn{2}{|c|}{$\begin{array}{c}\text { initial deltaic hydromorphic geosystems - wetlands, Tugay forest and pastures } \\
\text { Populus spp,, Salix spp., Eleagnus turkomanica, } \\
\text { Halimodendron halodendron, Climatis orientalis }\end{array}$} \\
\hline & \multicolumn{2}{|c|}{$\downarrow$} \\
\hline & $\begin{array}{l}\text { mesomorphic geosystems. } \\
\text { Phreatophitic communities and } \\
\text { some species with good } \\
\text { adaptation mode (Tamarix Sp., } \\
\text { Alhagi) }\end{array}$ & $\begin{array}{l}\text { NDVI values lowering, some increase of EBBI index, } \\
\text { retention of key components of spatial structure of } \\
\text { landscape. } \\
\text { Lowering of MNDWI index }\end{array}$ \\
\hline & \multicolumn{2}{|l|}{ 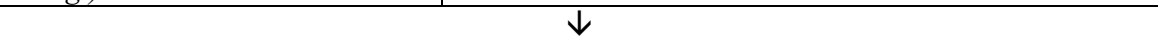 } \\
\hline & $\begin{array}{l}\text { halomorphic geosystems } \\
\text { Communities of halophitic } \\
\text { plants }\end{array}$ & $\begin{array}{l}\text { NDVI values lowering, slight growth of EBBI index } \\
\text { value, changes of key components of spatial structure } \\
\text { of landscape and growth of soil-salinization sensible } \\
\text { indexes - BI, and COSRI }\end{array}$ \\
\hline \multicolumn{3}{|r|}{$\downarrow$} \\
\hline \multicolumn{2}{|c|}{$\begin{array}{l}\text { xeromorphic } \\
\text { landscapes) }\end{array}$} & $\begin{array}{l}\text { significant NDVI lowering, trend to seasonal desert- } \\
\text { like fluctuation of SAVI, slow growth and stabilization } \\
\text { of NBLI and EBBI indexes, badlands formation, } \\
\text { slight lowering of BI and SI indexes }\end{array}$ \\
\hline
\end{tabular}

Fig.2. Diagram of landscape transformation with remote sensing indication signs. 


\section{Results}

We found that integration of landscape transformation model with optical change detection based on a spatial distribution and long-term dynamics of vegetation can be effective tool for estimation and prognosis of plant community's development and soil erosion. Comparison of the simulated results of landscape transformation with field da-ta demonstates good correlation of the predicted stages with detected plant communities, especially for halophitic and phreatophitic communities. Results for the psammophitic communities needs more complex interpretation due to combination of plant succession and intensive sandy soil erosion, sometime these sites demonstrates meta-stabilization.

\section{Discussion and conclusion}

In the current studies we want to discuss how integration of very sensitive methods of space images processing with model-oriented interpretation could lead to help in landscape mapping of transformed ecosystems and reveal some additional geoecological phenomena. There are some appropriate rules for the landscape transformation transition matrix derived from known plant succession studied before; using a set of spectral indexes to estimate deepness and speed of the transformation we can predict plant community compound.

Application of multiple optical indexes with landscape transformation model to describe current state and dynamics of desertified delta is effective instrument for geoecological studies of aridisation processes of former wetlands.

Also the phenomenon of landscape interference, when some non-stable state of local ecosystems (if few landscape-forming forces are compatible in power) could be meta-stable during decades, found a new confirmation for some parcel between xeromorphic and halomorphic states.

Complex approach based on optical index interpretation based on landscape transformation model could be used of operative geoecological mapping of non-stable landscapes as a tool for land use cartography and environment changes prognosis.

\section{References}

1. P. Reimov, D. Fayzieva. The Present State of the South Aral Sea Area in "The Aral Sea The Devastation and Partial Rehabilitation of a Great Lake" eds. Micklin P. et al., Springer-Verlag Berlin Heidelberg 171-206 (2014).

2. A.A. Rafikov, Sh.E. Ergashev, E. Khayadaorov. South Aral Sea basin desertification processes. Tashkent (1997)

3. A. Bannari, D. Morin, F. Bonn, R. Huete. A review of vegetation indices//Remote Sensing Reviews, 13(1-2), 95-120 (1995)

4. Y. Xie. Remote sensing imagery in vegetation mapping: a review//Journal of Plant Ecology, 1(1), 9-23 (2008)

5. M. Govender, K. Chetty, H. Bulcock. A review of hyperspectral remote sensing and its application in vegetation and water resource studies//Waters SA, 33(2), 145-151 (2007)

6. J. Xue, B. Su. Significant Remote Sensing Vegetation Indices: A Review of Developments and Applications//Journal of sensors. 1-17 (2017)

7. M.V. Konyuskova. Digital soil mapping of solonetz regions in the Northern Caspian lowland. Moscow. KMK Scientific press. (2014) 
8. V.A. Popov. Aral Problems and Amudaria delta landscapes. Tashkent, Fan, (1990)

9. A.A. Chibilve. Modern dynamics of ecosystem components in the deser-steppe regions of Russia Eds. et al. Moscow (2001)

10. V.S. Zaletaev. Ecosystem of rivers' floodplains: structure, dynamics, resource potential. Moscow, IWP RAS. (1997)

11. M.G. Turner, R.H. Gardner, R.V. O’Neill. Landscape ecology in theory and practice. Pattern and Process. Springer. 401 (2001)

12. A.B. Bakhiev, S.E. Treshkin, N.K. Mamutov. Geobotanic aspects of degradation and productivity enhancement for arid zone plant communities. Vestnik KKO AN RUz. №4. 11 (2010)

13. Z.V. Kuz'mina, S.E. Treshkin, N.K. Mamutov. An Influence of Climatic Changes on Formation of Vegetation Modelled in Dry Area of the Aral Sea //Arid Ecosystem. 10 (21), 82-94 (2004)

14. N.M. Novikova, Zh.V. Kuz'mina, T.V. Dilkareva, N.U. Trofimova. Preservation of the tugai bio-complex diversity within Amudarya and Syrdarya river deltas in aridization conditions // Ecological research and monitoring of the Aral Sea deltas. A basis for restoration. UNESCO Aral Sea Project. 1997-2000 Final Scientific reports. - Paris. (2001)

15. N.K. Mamutov. New approach and methods of nature protection activity management in Aral Sea region. Proceeding of the VIII INTECOL International Congress of Ecology/ Seoul. Korea. 176 (2002)

16. N.K. Mamutov, N.M. Novikova. Productivity of conditions of artificial watering at the Amudarya river delta. African Journal of Range \& Forage Science. 20(2), 147-152 (2003)

17. S.E. Treshkin, N.K. Mamutov. The modern state of vegetation cover of the Amudarya Delta and problems of biodiversity conservation. XVII International Botanical Congress/ Vienna, Austria 17-27 July, 578-579 (2005)

18. N.K. Mamutov, P.R. Reymov, V.A. Statov, S.J. Abdreymov Change of main type of flora of the south of the Aral Sea region as result of environment degradation. XVII International Botanical Congress Vienna, Austria, Europe 17-23 July, 617 (2005)

19. F.I. Khakimov. Soil and ameliorative conditions of desertified deltas. Puschino. (1989) 